\title{
What Affects the Relationships between Oil and Industrial Sector? Case of Eurozone
}

\author{
Melik Kamışl1 ${ }^{1}$, Serap Kamışl1 ${ }^{2}$, Fatih Temizel ${ }^{3}$ \& Ethem Esen ${ }^{3}$ \\ ${ }^{1}$ Assistant Professor, Department of Banking and Insurance, Bilecik Şeyh Edebali University, Bilecik, Turkey \\ ${ }^{2}$ Assistant Professor, Department of Banking and Finance, Bilecik Şeyh Edebali University, Bilecik, Turkey \\ ${ }^{3}$ Associate Professor, Faculty of Economics and Administrative Sciences, Eskişehir, Anadolu University, Turkey \\ Correspondence: Serap Kamışlı, School of Applied Sciences, Bilecik Şeyh Edebali University, 11300 Yeşilkent \\ Mh. 1.Cd. Bilecik, Turkey. Tel: 90-0228-214-969. E-mail: satbas@ gmail.com
}

Received: June 13, 2017

Accepted: July 22, 2017

Online Published: August 10, 2017

doi:10.5539/ijef.v9n9p52

URL: https://doi.org/10.5539/ijef.v9n9p52

\begin{abstract}
Oil, which is one of the fundamental energy sources, is an important cost item especially for industrial sector. Increases in oil prices decrease the profits of the firms by causing increase in the production costs. For this reason, it is claimed that there is a strong relationship between oil price and industrial sector profitability. On the other hand, oil is an alternative investment vehicle that can be included to the portfolio. Therefore, in this study the relationships between oil price and industrial sector returns of European countries are analyzed with Maki (2012) cointegration test under multiple structural breaks, on the basis of European Debt Crisis. The results show that announcements of credit rating agencies, elections, resignations, announcements of European Central Bank and IMF, recovery packages and economic developments cause structural breaks in relationships. Results also indicate that there is no cointegration between oil price and industrial sector returns of Austria, Belgium and Holland.
\end{abstract}

Keywords: oil price, cointegration, structural break, diversification

\section{Introduction}

Oil is qualified as lifeblood of modern economies. There is a high correlation between increase in the industrial production and oil demand, and as modernization increases demand to oil increases significantly. Oil is one of fundamental components of production process, such as capital, labor force and intermediate goods. Changes in price of these inputs affect cash flows of companies. Increases in oil prices increase production costs and high production costs decrease value of company stocks by decreasing cash flows. Effects of increases in oil prices on companies change depending on if the company is user or producer of oil and oil products. But because of the number of company that uses oil and oil products in production process is higher than the number of producer of these products, it is expected that general effects of increases in prices are negative (Basher \& Sadorsky, 2006).

Fluctuations in oil prices affect stock returns through different channels. In financial theory, the value of a stock is equal to discounted value of expected future cash flows of stock. These expected cash flows are responsive to many economic and macroeconomic factors, such as inflation, interest rates, production costs, exchange rates, economic growth, investor and customer confidence, which are affected from oil shocks. When considered in this context, it can be said that oil prices have an effect on stock returns (Arouri \& Nguyen, 2010).

One of the most studied issues in financial literature is the determination of the factors affecting the stock market. Identification of these factors and determination of direction and degree of the relationships are important for both investors and policy makers. Although there are too many theoretical and empirical studies in the literature, there is no consensus on the number and features of the factors that affect stock returns. On the other hand, identified relationships can change because of time-varying dynamics as it is in crises times. In this context, especially when the crises experienced in recent years and the large increases and decreases experienced in oil prices are considered, it can be said that the effects of oil prices on stock returns should be re-examined.

The main purpose of diversification is to include the portfolio the variables which are negatively and lowly correlated or noncointegrated. For this reason, investors should consider the relationships between oil price and industrial sector. But, 2009 Greek Debt Crisis, with 2008 Global Crisis, triggered the financial problems 
especially in Portugal, Ireland, Spain, Italy and Iceland and finally turned to European Debt Crisis. When this period is considered, it is thought that the relationships between oil price and sectoral profitability changed because of the changing risk perception depending on the crises. In this context, the purpose of this study is to determine the cointegration relationships between oil price and industrial sector returns. In line with this purpose, the cointegration between oil price and industrial sector returns of European countries will be analyzed by Maki (2012) cointegration test under multiple structural breaks and the events that cause structural breaks will be determined.

The remainder of this paper is organized as follows. In the next section the literature on the relationships between oil prices and stock markets are given. In Section III, the variables, the data and the methodology of the study are presented. In section IV descriptive statistics of the series and empirical results are given and section V concludes.

\section{Literature Review}

In recent years important changes occurred in oil prices and this situation has led the interest of academics and policy makers to the linkages between oil prices and stock returns as it is in 1970s. In his study, Arouri (2011) investigated the response of industrial indices to oil price changes and determined that degree of response to price changes is different for sectors. Arouri et al. (2011) examined the volatility spillovers between oil prices and stock returns and discussed the usability in portfolio management. By using VAR-GARCH models volatility spillovers were determined and optimal weights and hedge ratios were given for diversification.

Basher and Sadorsky (2006) analyzed the effects of oil price changes on stock markets of emerging countries. Empirical results indicated that oil price risk affect the stock returns in emerging countries. Papapetrou (2001) studied on the relationships among oil price shocks, economic activity, stock markets and unemployment. The results of VAR model showed that oil price is an important variable in explaining stock price movements. Basher, et al. (2012) researched the dynamic relationships among oil prices, exchange rates and emerging stock markets. Results demonstrated that positive oil shocks decrease the returns in emerging countries, and increases in stock prices cause increase in oil prices. Kilian and Park (2009) detected the effects of oil price shocks on US stock markets and concluded that the response of returns to the shocks change depending on if the shock is supply-driven or demand-driven.

Arouri et al. (2011) examined return and volatility spillovers between oil prices and stock markets of Gulf Arab Countries and found that there are return and volatility spillovers between oil prices and stock markets, which are important for portfolio management. Fayyad and Daly (2011) investigated the relationships between oil prices and stock returns by using VAR methodology. The analysis results show that oil's power of explaining the stock returns increased in Global Crisis period and when the oil prices increased. Similarly, Mohanty et al. (2011) researched the relationships between oil price movements and stock returns and concluded that oil prices affect stock returns.

When the studies that investigate the relationships between oil prices and stock returns are considered, it is seen that there is no industrial sector-specific studies that analyze the effects of recent changes in oil prices. In this context, it is thought that the analysis of the relationships between industrial sector indices and oil price will present useful information to the investors who are willing to invest in the stocks of industrial companies. Therefore, in the next section the relationships between oil price and industrial sector indices of 17 European countries will be analyzed by cointegration tests under structural breaks.

\section{Data and Methodology}

The purpose of this study is to examine the cointegration relations between oil price and industrial sector indices of European countries. In this context, we used Kapetanios (2005) unit root test under multiple structural breaks and Maki (2012) cointegration test under multiple structural breaks.

If the time span of the analysis is length, then the possibility of structural breaks in the variables increases. Therefore, the unit root tests that are applied by not considering the structural breaks may give misleading results about the stationarity of the series. In his study, by analyzing the stationarity of the series, Perron (1989) expressed the negative situations when the structural breaks are not considered. After Perron revealed the importance of structural breaks in unit root tests, many unit root tests that consider the structural breaks were developed (Zivot-Andrews, 1992; Lumsdaine-Papell, 1997; Perron, 1997; Ng-Perron, 2001; and Lee-Strazicich, 2003). However, study of Perron was criticized because of the problems such as the determination of structural breaks externally and determination of break points wrongly.

Later, there have been developed unit root tests in which structural breaks are determined internally. But these 
tests were also criticized because of the determination of the break number externally. Time series may have multiple structural breaks and if the stationarity of the series are checked with a unit root test that allows only one break, this may cause misleading results. In unit root test which is developed by Kapetanios (2005), it is allowed till to the $\mathrm{m}$ structural breaks and, the date and the number of structural breaks are determined internally. The model that is used in Kapetanios (2005) test is as follows;

$$
\begin{gathered}
y_{t}=\alpha_{0}+\alpha_{1} t+\beta y_{t-1}+\sum_{i=1}^{k} \gamma_{i} \Delta y_{t-i}+\sum_{i=1}^{m} \emptyset_{i} D U_{i, t}+\sum_{i=1}^{m} \varphi_{i} D T_{i, t}+\epsilon_{t} \\
D U_{i, t}=1\left(t<T_{b, i}\right) \\
D U_{i, t}=1\left(t<T_{b, i}\right)\left(t-T_{b, i}\right)
\end{gathered}
$$

In model, $y_{t}$ expresses the time series for which the stationarity is examined. $D U$ and $D T$ are the dummy variables which indicate structural breaks in constant and trend respectively. The null hypothesis of the test is $\beta=1$, in other words, the series is non stationary. In Kapetanios test, in terms of calculation practice structural break dates are calculated by using the algorithm suggested by Bai and Perron (1998). In test procedure whole period is considered as a possible structural break date and the break date of model which has the minimum sum of squares of error terms is selected as the first structural break date.

$$
S S R=\sum_{t=k+2}^{T}\left(y_{t}-\hat{\alpha}_{0}-\hat{\alpha}_{1} t+\hat{\beta} y_{t-1}+\sum_{i=1}^{k} \hat{\gamma}_{i} \Delta y_{t-i}+\sum_{i=1}^{m} \widehat{\emptyset}_{i} D U_{1, t}+\sum_{i=1}^{m} \hat{\varphi}_{i} D T_{1, t}\right)^{2}
$$

In the next step, the first structural break date is fixed and the second structural break date is searched. This process continues until to the $m$ breaks and, the dates and the number of the structural break of the model which has the minimum t statistic is taken (Capistrán \& Ramos-Francia, 2009). The critical values that are needed to test the null unit root hypothesis are given at Table 1 in the study of Kapetanios (2005).

Cointegration tests may give misleading results if the series that are used in the analyses have structural breaks, as in unit root tests (Gregory \& Hansen, 1996). Therefore structural breaks should be considered in cointegration tests. In the literature there are several cointegration tests that consider the structural breaks. One of them is the test developed by Gregory and Hansen (1996). But this test considers only one structural break. Similarly, cointegration tests of Carrion-i-Silvestre and Sanso (2006) and Westerlund and Edgerton (2006) allow only one structural break. The test proposed by Hatemi-J (2008) examines the cointegration relationship for the presence of two structural breaks.

Maki (2012) developed a test that consider more than one structural break. Besides allowing 3 or more structural breaks, mentioned method filled a gap in the literature by determining the number of structural breaks internally. Maki proposed 4 models to test the cointegration relationships under structural breaks. These models are as follows;

$$
\begin{gathered}
y_{t}=\mu+\sum_{i=1}^{k} \mu_{i} D_{i, t}+\beta^{\prime} x_{t}+u_{t} \\
y_{t}=\mu+\sum_{i=1}^{k} \mu_{i} D_{i, t}+\beta^{\prime} x_{t}+\sum_{i=1}^{k} \beta_{i}^{\prime} x_{t} D_{i, t}+u_{t} \\
y_{t}=\mu+\sum_{i=1}^{k} \mu_{i} D_{i, t}+\gamma t+\beta^{\prime} x_{t}+\sum_{i=1}^{k} \beta_{i}^{\prime} x_{t} D_{i, t}+u_{t} \\
y_{t}=\mu+\sum_{i=1}^{k} \mu_{i} D_{i, t}+\gamma t+\sum_{i=1}^{k} \gamma_{i} t D_{i, t}+\beta^{\prime} x_{t}+\sum_{i=1}^{k} \beta_{i}^{\prime} x_{t} D_{i, t}+u_{t}
\end{gathered}
$$

In Maki (2012) test whole period is considered as a possible structural break date and t statistics are calculated. The number of structural breaks of the model, which has the minimum t statistic, is selected as the appropriate number of structural breaks. The null hypothesis of the test is that there is no cointegration between variables, and the alternative hypothesis is that there is a cointegration relationship between the variables under $\mathrm{m}$ structural breaks determined by the selected model. The critical values that are needed to test the hypotheses are calculated by Monte Carlo simulation and presented at Table 1 in the study of Maki (2012). Because the analysis period contains European Debt Crisis, we used both traditional and Kapetanios unit root tests to determine the stationarity of the series. In the next step, the relationship between oil price and nonstationary European industrial sector return series (I(1)) is investigated by Maki cointegration test under structural breaks.

In the analyses logarithmic oil price (OIL) and monthly return series of Austria (AUS), Belgium (BEL), Denmark (DNK), Finland (FIN), France (FRA), Germany (DEU), Greece (GRC), Italy (ITA), Netherlands (NLD), Norway (NOR), Poland (POL), Portugal (PRT), Spain (ESP), Sweden (SWE), Switzerland (CHE), United Kingdom (GBR) and Turkey (TUR) industrial sector indices gathered from Datastream were used. The data set covers the period between November 2009, which is the official start of the Greek Debt Crisis, and January 2016.

\section{Empirical Results}

For portfolio and risk management determination of cointegration relationships between the variables is 
important. But descriptive statistics of the variables also present valuable information that can be used in management process. For this reason, before cointegration analyses descriptive statistics of the series are calculated and given at Table 1 .

Table 1. Descriptive statistics of oil price and industrial sector return of European countries

\begin{tabular}{ccccccccccc}
\hline & Mean & Median & Max. & Min. & Std. Dev. & Skewness & Kurtosis & Jarque Bera & ADF & PP \\
\hline OIL & 4.392 & 4.489 & 4.71 & 3.49 & 0.29 & -1.42 & 4.10 & $28.90^{*}$ & 0.16 & 0.61 \\
AUS & -0.002 & 0.006 & 0.13 & -0.23 & 0.06 & -0.63 & 4.40 & $10.86^{*}$ & $-6.92^{*}$ & $-6.95^{*}$ \\
BEL & 0.004 & 0.012 & 0.12 & -0.17 & 0.05 & -0.98 & 4.85 & $22.33^{*}$ & $-6.66^{*}$ & $-6.66^{*}$ \\
CHE & -0.001 & -0.001 & 0.11 & -0.22 & 0.05 & -1.00 & 6.41 & $48.18^{*}$ & $-7.51^{*}$ & $-7.51^{*}$ \\
DEU & 0.002 & 0.008 & 0.13 & -0.23 & 0.06 & -0.88 & 5.63 & $30.91^{*}$ & $-7.83^{*}$ & $-7.84^{*}$ \\
DNK & 0.008 & 0.015 & 0.12 & -0.18 & 0.05 & -0.99 & 5.37 & $29.49^{*}$ & $-6.38^{*}$ & $-6.36^{*}$ \\
ESP & -0.009 & -0.010 & 0.16 & -0.20 & 0.07 & -0.41 & 3.23 & $12.20^{*}$ & $-7.56^{*}$ & $-7.57^{*}$ \\
FIN & 0.012 & 0.015 & 0.09 & -0.15 & 0.04 & -0.95 & 4.79 & $21.04^{*}$ & $-7.95^{*}$ & $-7.93^{*}$ \\
FRA & 0.000 & 0.005 & 0.12 & -0.29 & 0.07 & -1.24 & 5.88 & $44.38^{*}$ & $-7.00^{*}$ & $-7.00^{*}$ \\
GBR & 0.000 & 0.006 & 0.09 & -0.18 & 0.04 & -1.06 & 6.08 & $42.97^{*}$ & $-7.99^{*}$ & $-8.00^{*}$ \\
GRC & -0.070 & -0.073 & 0.45 & -0.75 & 0.18 & -0.30 & 5.43 & $19.39^{*}$ & $-7.91^{*}$ & $-7.89^{*}$ \\
ITA & -0.006 & 0.003 & 0.14 & -0.23 & 0.08 & -0.44 & 3.37 & $22.78^{*}$ & $-7.41^{*}$ & $-7.36^{*}$ \\
NLD & 0.001 & 0.003 & 0.15 & -0.30 & 0.07 & -1.17 & 6.19 & $48.38^{*}$ & $-7.51^{*}$ & $-7.51^{*}$ \\
NOR & 0.004 & 0.012 & 0.10 & -0.20 & 0.05 & -0.95 & 4.73 & $20.44^{*}$ & $-6.72^{*}$ & $-6.57^{*}$ \\
POL & -0.001 & 0.002 & 0.09 & -0.16 & 0.04 & -0.31 & 3.72 & $15.78^{*}$ & $-7.50^{*}$ & $-7.48^{*}$ \\
PRT & -0.033 & -0.020 & 0.23 & -0.33 & 0.12 & -0.25 & 5.82 & $8.89^{*}$ & $-5.58^{*}$ & $-5.55^{*}$ \\
SWE & 0.008 & 0.014 & 0.11 & -0.18 & 0.05 & -0.95 & 5.86 & $36.25^{*}$ & $-7.66^{*}$ & $-7.63^{*}$ \\
TUR & 0.001 & -0.002 & 0.13 & -0.13 & 0.06 & -0.01 & 3.64 & $9.41^{*}$ & $-7.25^{*}$ & $-7.47^{*}$ \\
\hline
\end{tabular}

As it can be seen from descriptive statistics, the sector returns which have the lowest average return are sector returns of Greece, Portugal, Spain and Italy respectively. In accordance with this, the sector returns which have the highest risk are sector returns of Greece, Portugal, Spain and Italy respectively. Results especially indicates the statistics of the countries called PIGS which were deeply affected from European Debt Crisis. On the other hand, all of the series, including oil price, have negative kurtosis values, and high skewness values shows that big shocks are possible and series move away normal distribution.

Stationarity of the series are firstly tested by Augmented Dickey Fuller (ADF) and Philips-Perron (PP) unit root tests which do not consider structural breaks. Results of both tests show that series are stationary. But because of the analysis period includes the European Debt Crisis, in the next step Kapetanios unit root test is applied to the series and results of the models that allow breaks in constant and trend are presented at Table 2.

Table 2. Kapetanios unit root test results

\begin{tabular}{|c|c|c|c|c|c|c|c|}
\hline Variable & Test Statistic & & & eak Dates & & & First Difference \\
\hline OIL & -6.657 & 2010M07 & 2011M07 & 2012M04 & 2014M09 & - & $-9.414 *$ \\
\hline AUS & -6.161 & 2010M07 & 2012M01 & 2013M09 & 2015M01 & - & $-9.233 *$ \\
\hline BEL & -7.904 & 2010M12 & 2011M12 & 2012M11 & 2014M06 & 2015M02 & $-12.363 *$ \\
\hline CHE & -7.362 & 2010M08 & 2011M04 & 2012M07 & $2015 \mathrm{M} 02$ & - & $-9.920 *$ \\
\hline DEU & -6.258 & 2011M11 & 2013M02 & $2013 \mathrm{M} 10$ & 2015M01 & - & $-13.113^{*}$ \\
\hline DNK & $-9.485^{*}$ & 2010M12 & $2011 \mathrm{M} 11$ & 2013M03 & 2014M04 & 2015M01 & - \\
\hline ESP & -7.093 & 2010M10 & $2011 \mathrm{M} 12$ & $2015 \mathrm{M} 03$ & - & - & $-9.869 *$ \\
\hline FIN & $-9.176 *$ & 2011M01 & 2011M09 & 2012M07 & 2014M02 & 2014M12 & - \\
\hline FRA & $-8.128 *$ & $2010 \mathrm{M} 12$ & 2011M09 & 2012M05 & - & - & - \\
\hline GBR & $-9.738 *$ & $2010 \mathrm{M} 12$ & 2011M09 & 2014M07 & $2015 \mathrm{M} 03$ & & - \\
\hline GRC & -5.286 & 2010M08 & $2012 \mathrm{M} 12$ & - & - & - & $-9.491 *$ \\
\hline ITA & -6.557 & 2010M08 & 2012M08 & 2013M06 & 2014M05 & - & $-10.841 *$ \\
\hline NLD & -5.829 & 2010M12 & 2011M11 & 2013M01 & 2014M06 & 2015M02 & $-8.729 *$ \\
\hline NOR & -6.371 & 2010M09 & 2011M09 & 2012M06 & 2015M01 & - & $-9.722 *$ \\
\hline POL & $-9.781 *$ & 2011M01 & 2011M09 & 2012M05 & - & - & - \\
\hline PRT & -6.428 & 2011M03 & 2012M05 & 2013M05 & 2014M06 & - & $-9.711 *$ \\
\hline SWE & -6.035 & 2011M09 & 2012M06 & $2014 \mathrm{M} 10$ & - & - & $-10.940 *$ \\
\hline TUR & -7.739 & $2010 \mathrm{M} 10$ & 2011M09 & $2012 \mathrm{M} 10$ & 2013M06 & $2015 \mathrm{M} 02$ & $-11.392 *$ \\
\hline
\end{tabular}


Test results seen at Table 2 show that industrial sector returns of Denmark, Finland, France, United Kingdom and Poland are stationary when the structural breaks are considered. These results indicate that external shocks that affect industrial sector returns of Denmark, Finland, France, United Kingdom and Poland are temporary. On the other hand, determined structural break dates refer to country basis events and economic and political events beginning with European Debt Crisis that affect all markets. Especially when the process, that began with the problems occurred in Greece and spread to other European countries with domino effect, is examined, it is seen that events that occurred in a country affect not only country itself but also other markets.

In the analyses, announcements of credit rating agencies in 2010 July-Portugal, 2010 August-Ireland, 2010 September-Spain, 2011 January-Greece, 2011 September-Italy were determined as the events that caused structural breaks. Another reason of the structural breaks was political events such as resignation of Italy's prime minister Silvio Berlusconi, Greece's prime minister George Papandreou in 2011 November and IMF Managing Director Rodrigo Rato in 2012 May. Besides resignations, elections of Spain-2011 November, France and Greece-2012 May and Greece 2014 December/ 2015 January caused structural breaks.

Empirical results also indicate to economic developments as the reason of structural breaks. Press release of European Central Bank (ECB) in 2012 September, rate cut decision in May 2013 and quantitative easing dates appear as the structural break dates. On the other hand, negative data announcements about German and French economies, and exit of Portugal from bailout programme in May 2014 are seen as the events that caused structural breaks.

After determination of stationarity of the series, Maki cointegration test is applied to the series, which are not stationary at level, in order to investigate the existence of cointegration. For this reason, industrial sector returns of Denmark, Finland, France, United Kingdom and Poland were excluded from the scope of analysis. Because of the structure of period and series, Model 3 with constant and trend is chosen and results are given at Table 3.

Table 3. Results of Maki cointegration tests

\begin{tabular}{|c|c|c|c|c|}
\hline & Model 0 & Model 1 & Model 2 & Model 3 \\
\hline \multirow{2}{*}{ AUS } & -4.583 & -4.980 & -5.080 & 5.839 \\
\hline & $(-5.416)$ & $(-5.833)$ & $(-6.596)$ & $(-8.004)$ \\
\hline \multirow{2}{*}{ BEL } & -5.418 & -5.722 & -5.454 & -5.472 \\
\hline & $(-5.959)$ & $(-6.193)$ & $(-6.915)$ & $(-8.004)$ \\
\hline \multirow{2}{*}{ CHE } & $-6.446^{*}$ & $-6.288^{*}$ & $-7.502 *$ & $-6.733^{*}$ \\
\hline & $(-5.959)$ & $(-6.193)$ & $(-6.915)$ & $(-6.048)$ \\
\hline \multirow{2}{*}{ DEU } & $-6.494 *$ & $-6.711 *$ & $-5.971 *$ & $-6.695^{*}$ \\
\hline & $(-5.776)$ & $(-6.193)$ & $(-5.863)$ & $(-6.048)$ \\
\hline \multirow{2}{*}{ ESP } & $\mathbf{- 8 . 0 2 4} *$ & $-7.201 *$ & $-8.351 *$ & $-9.073 *$ \\
\hline & $(-5.709)$ & $(-5.524)$ & $(-6.915)$ & $(-7.082)$ \\
\hline \multirow{2}{*}{ GRC } & $-8.357^{*}$ & $-7.876^{*}$ & $-8.834 *$ & -8.694* \\
\hline & $(-5.959)$ & $(-5.708)$ & $(-5.457)$ & $(-6.048)$ \\
\hline \multirow{2}{*}{ ITA } & $-7.665^{*}$ & $-8.062 *$ & $-8.725^{*}$ & $-7.742 *$ \\
\hline & $(-5.709)$ & $(-5.708)$ & $(-6.915)$ & $(-6.048)$ \\
\hline \multirow{2}{*}{ NLD } & -4.753 & -5.265 & -5.515 & -5.548 \\
\hline & $(-5.776)$ & $(-5.708)$ & $(-6.915)$ & $(-6.620)$ \\
\hline \multirow{2}{*}{ NOR } & -8.019* & $-7.462 *$ & $-7.851 *$ & $-7.168 *$ \\
\hline & $(-5.776)$ & $(-5.708)$ & $(-6.596)$ & $(-6.048)$ \\
\hline \multirow{2}{*}{ PRT } & $-6.236 *$ & $-7.148 *$ & $-7.843^{*}$ & $-8.579 *$ \\
\hline & $(-5.959)$ & $(-6.059)$ & $(-6.915)$ & $(-7.553)$ \\
\hline \multirow{2}{*}{ SWE } & $-8.088 *$ & $-8.447^{*}$ & $-8.183^{*}$ & $-8.285^{*}$ \\
\hline & $(-5.709)$ & $(-5.708)$ & $(-5.457)$ & $(-6.048)$ \\
\hline \multirow{2}{*}{ TUR } & $-11.837 *$ & $-16.169^{*}$ & $-18.575^{*}$ & $-14.808 *$ \\
\hline & $(-5.959)$ & $(-5.524)$ & $(-6.915)$ & $(-8.004)$ \\
\hline
\end{tabular}

According to Maki cointegration test results there are cointegration relations between oil price and industrial sector returns of Switzerland, Germany, Spain, Greece, Italy, Norway, Portugal, Sweeden and Turkey under structural breaks. In other words, oil price and industrial sector return of the aforementioned countries move together in the long-run. Therefore, for the investors who are willing to invest in oil and industrial sector, it is not possible to diversify portfolio by investing in these instruments. 
Structural break dates determined with Maki cointegration tests are given at Appendix-1. When the break dates are investigated, it is seen that economic and political events such as announcements of credit rating agencies, elections, resignations, recovery packages, announcements of European Central Bank and IMF cause breaks, similar to Kapetanios unit root test indicated. For example results show that events such as decrease in rating of Spain and Italy in 2011 October and 2013 July Greek reform caused structural breaks. Another important finding of the study is that there is no cointegration between oil and industrial sector returns of Austria, Belgium and Holland. This result indicate that investors who invest in oil can diversify their portfolios by investing in industrial sector index of these countries.

\section{Conclusion}

The purpose of this study is to determine the relationships, between oil price and industrial sector indices of European countries, which are thought to be changed after the European Debt Crisis. It is not irrational to expect a cointegration relationship between these variables in the long run, when the effects of oil price on the profitability of industrial sector are considered. Therefore, it can be said that it is not possible to decrease the portfolio risk and benefit from diversification by including these instruments to the portfolio. However, cointegration analyses can produce different results when the structural breaks are considered, especially in the periods there occur events that affect markets deeply such as European Debt Crisis. In this context, firstly stationarity of oil price and industrial sector returns of European countries are tested via Kapetanios unit root test. According to unit root test results industrial sector returns of Denmark, Finland, France, United Kingdom and Poland are stationary. In other words, the effects of external shocks on industrial sector returns of these countries are temporary.

Based on the results of Kapetanios unit root test, the relationships between oil price and nonstationary European industrial sector return series are analyzed by Maki cointegration test. Maki test results showed that there are cointegration relationships between oil price and industrial sector return of Switzerland, Germany, Spain, Greece, Italy, Norway, Sweden and Turkey. Also, both test results indicated that, announcements of European Central Bank and IMF, elections, resignations, economic developments, announcements of credit rating agencies and decisions, which caused economic and political events, such as recovery packages caused structural breaks. On the other hand, there is no cointegration relationship between oil price and industrial sector return of Austria, Belgium and Holland. This results indicate that, investors can diversify their portfolios by investing in these stock markets besides oil, and vice versa.

Especially in crisis periods, to sustain their presence and profitability firms may invest more in financial instruments besides their main activities. Therefore, not only for investors but also for firms it will be useful to analyze deeply the industrial sector returns of Austria, Belgium and Holland in further studies for efficient portfolio and risk management.

\section{Acknowledgements}

This study is the summarized version of 1602E051 numbered research project with the title "Analysis of Asymmetric Effects of Commodity Price Changes on Sectoral Indices of European Countries" supported by Anadolu University.

\section{References}

Arouri, M. E. H., \& Nguyen, D. K. (2010). Oil prices, stock markets and portfolio investment: Evidence from sector analysis in Europe over the last decade. Energy Policy, 38(8), 4528-4539. https://doi.org/10.1016/j.enpol.2010.04.007

Arouri, M. E. H. (2011). Does crude oil move stock markets in Europe? A sector investigation. Economic Modelling, 28(4), 1716-1725. https://doi.org/10.1016/j.econmod.2011.02.039

Arouri, M. E. H., Jouini, J., \& Nguyen, D. K. (2011). Volatility spillovers between oil prices and stock sector returns: Implications for portfolio management. Journal of International Money and Finance, 30(7), 1387-1405. https://doi.org/10.1016/j.jimonfin.2011.07.008

Arouri, M. E. H., Lahiani, A., \& Nguyen, D. K. (2011). Return and volatility transmission between world oil prices and stock markets of the GCC countries. Economic Modelling, 28(4), 1815-1825. https://doi.org/10.1016/j.econmod.2011.03.012

Bai, J., \& Perron, P. (1998). Estimating and Testing Linear Models with Multiple Structural Changes. Econometrica, 66(1), 47-78. https://doi.org/10.2307/2998540

Basher, S. A., \& Sadorsky, P. (2006). Oil price risk and emerging stock markets. Global Finance Journal, 17(2), 
224-251. https://doi.org/10.1016/j.gfj.2006.04.001

Basher, S. A., Haug, A. A., \& Sadorsky, P. (2012). Oil prices, exchange rates and emerging stock markets. Energy Economics, 34(1), 227-240. https://doi.org/10.1016/j.eneco.2011.10.005

Capistrán, C., \& Ramos-Francia, M. (2009). Inflation dynamics in Latin America. Contemporary Economic Policy, 27(3), 349-362. https://doi.org/10.1111/j.1465-7287.2008.00128.x

Carrion-i-Silvestre, J. L., \& Sansó, A. (2006). Testing the null of cointegration with structural breaks. Oxford Bulletin of Economics and Statistics, 68(5), 623-646. https://doi.org/10.1111/j.1468-0084.2006.00180.x

Fayyad, A., \& Daly, K. (2011). The impact of oil price shocks on stock market returns: Comparing GCC countries with the UK and USA. Emerging Markets Review, 12(1), 61-78. https://doi.org/10.1016/j.ememar.2010.12.001

Gregory, A. W., \& Hansen, B. E. (1996). Tests for cointegration in models with regime and trend shifts. Oxford $\begin{array}{lllll}\text { Bulletin of } \quad \text { Economics } & \text { and }\end{array}$ https://doi.org/10.1111/j.1468-0084.1996.mp58003008.x

Hatemi, J. A. (2008). Tests for cointegration with two unknown breaks with an application to the financial market integration. Empirical Economics, 35(3), 497-505. https://doi.org/10.1007/s00181-007-0175-9

Kapetanios, G. (2005). Unit-root testing against the alternative hypothesis of up to $\mathrm{m}$ structural breaks. Journal of Time Series Analysis, 26(1), 123-133. https://doi.org/10.1111/j.1467-9892.2005.00393.x

Kilian, L., \& Park, C. (2009). The impact of oil price shocks on the U.S. stock market. International Economic Review, 50(4), 1267-1287. https://doi.org/10.1111/j.1468-2354.2009.00568.x

Lee, J., \& Strazicich, M. C. (2003). Minimum lagrange multiplier unit root test with two structural breaks. The Review of Economics and Statistics, 85(4), 1082-1089. https://doi.org/10.1162/003465303772815961

Lumsdaine, R. L., \& Papell, D. H. (1997). Multiple trend breaks and the unit root hypothesis. The Review of Economics and Statistics, 79(2), 212-218. https://doi.org/10.1162/003465397556791

Maki, D. (2012). Tests for cointegration allowing for an unknown number of breaks. Economic Modelling, 29(5), 2011-2015. https://doi.org/10.1016/j.econmod.2012.04.022

Mohanty, S. K., Nandha, M., Turkistani, A. Q., \& Alaitani, M. Y. (2011). Oil price movements and stock market returns: Evidence from Gulf Cooperation Council (GCC) countries. Global Finance Journal, 22(1), 42-55. https://doi.org/10.1016/j.gfj.2011.05.004

Ng, S., \& Perron, P. (2001). Lag length selection and the construction of unit root tests with good size and power, Econometrica, 69(6), 1519-1554. https://doi.org/10.1111/1468-0262.00256

Papapetrou, E. (2001). Oil price shocks, stock market, economic activity and employment in Greece. Energy Economics, 23(5), 511-532. https://doi.org/10.1016/S0140-9883(01)00078-0

Perron, P. (1989). The Great Crash, the oil price shock and the unit root hypothesis. Econometrica, 57(6), 1361-1401. https://doi.org/10.2307/1913712

Perron, P. (1997). Further evidence on breaking trend functions in macroeconomic variables. Journal of Econometrics, 80(2), 355-385. https://doi.org/10.1016/S0304-4076(97)00049-3

Westerlund, J., \& Edgerton, D. L. (2006). New improved tests for cointegration with structural breaks. Journal of Time Series Analysis, 28(2), 188-244. https://doi.org/10.1111/j.1467-9892.2006.00504.x

Zivot, E., \& Andrews, D. W. K. (1992). Further evidence on the Great Crash, the oil price shock, and the unit root hypothesis. Journal of Business and Economic Statistics, 10(3), 251-270. https://doi.org/10.2307/1391541 


\section{Appendix}

Results of Maki Cointegration Tests

\begin{tabular}{|c|c|c|c|c|}
\hline & $\begin{array}{c}\text { Model 0: } \\
\text { Level Shift }\end{array}$ & $\begin{array}{c}\text { Model 1: } \\
\text { Level Shift with Trend }\end{array}$ & $\begin{array}{c}\text { Model 2: } \\
\text { Regime Shifts }\end{array}$ & $\begin{array}{c}\text { Model 3: } \\
\text { Regime Shifts with Trend }\end{array}$ \\
\hline AUS & 2011M03; 2011M11 & $\begin{array}{l}\text { 2011M07; 2011M12; } \\
\text { 2015M01 }\end{array}$ & $\begin{array}{l}\text { 2011M07; 2011M11; } \\
\text { 2013M08; 2014M10 }\end{array}$ & $\begin{array}{c}\text { 2011M03; 2012M08; } \\
\text { 2013M01; 2013M08; } \\
\text { 2015M08 }\end{array}$ \\
\hline BEL & $\begin{array}{c}\text { 2010M05; 2010M10; } \\
\text { 2012M06; 2013M05; } \\
\text { 2014M10 }\end{array}$ & $\begin{array}{c}\text { 2011M07; 2012M01; } \\
\text { 2012M05; 2012M12; } \\
\text { 2014M10 }\end{array}$ & $\begin{array}{l}\text { 2010M12; 2011M05; } \\
\text { 2012M05; 2013M05; } \\
\text { 2014M10 }\end{array}$ & $\begin{array}{c}\text { 2011M03; 2011M07; } \\
\text { 2011M11; 2012M06; } \\
\text { 2014M10 }\end{array}$ \\
\hline CHE & $\begin{array}{c}\text { 2010M05; 2010M09; } \\
\text { 2012M04; 2013M05; } \\
\text { 2014M10 }\end{array}$ & $\begin{array}{c}\text { 2011M05; 2011M11; } \\
\text { 2012M06; 2014M08; } \\
\text { 2015M01 }\end{array}$ & $\begin{array}{c}\text { 2010M06; 2011M11; } \\
\text { 2012M11; 2013M08; } \\
\text { 2015M05 }\end{array}$ & 2011M08 \\
\hline DEU & $\begin{array}{l}\text { 2011M07; 2011M11; } \\
\text { 2013M11; 2015M04 }\end{array}$ & $\begin{array}{c}\text { 2011M01; 2012M01; } \\
\text { 2013M05; 2014M12; } \\
\text { 2015M04 }\end{array}$ & 2011M02; 2011M11 & 2012M06 \\
\hline ESP & 2012M05 & 2012M05 & $\begin{array}{c}\text { 2011M05; 2011M12; } \\
\text { 2012M05; 2012M10; } \\
\text { 2015M01 }\end{array}$ & $\begin{array}{c}\text { 2011M09; 2012M05; } \\
\text { 2014M12 }\end{array}$ \\
\hline GRC & $\begin{array}{c}\text { 2011M02; 2011M09; } \\
\text { 2012M08; 2013M01; } \\
\text { 2015M07 }\end{array}$ & 2012M02; 2012M06 & 2012M06 & 2012M06 \\
\hline ITA & 2012M06 & 2012M02; 2012M07 & $\begin{array}{c}\text { 2011M02; 2012M05; } \\
\text { 2013M01; 2013M08; } \\
\text { 2014M05 }\end{array}$ & 2012M06 \\
\hline NLD & $\begin{array}{l}\text { 2011M03; 2011M09; } \\
\text { 2012M07; 2015M04 }\end{array}$ & 2012M02; 2012M06 & $\begin{array}{c}\text { 2010M10; 2011M04; } \\
\text { 2011M10; 2012M02; } \\
\text { 2012M06 }\end{array}$ & 2011M09; 2012M05 \\
\hline NOR & $\begin{array}{l}\text { 2011M04; 2011M09; } \\
\text { 2012M06; 2015M07 }\end{array}$ & 2010M10; 2012M07 & $\begin{array}{l}\text { 2010M05; 2010M10; } \\
\text { 2012M02; 2012M06 }\end{array}$ & 2012M05 \\
\hline PRT & $\begin{array}{c}\text { 2012M08; 2013M01; } \\
\text { 2013M11; 2014M04; } \\
\text { 2015M07 }\end{array}$ & $\begin{array}{l}\text { 2012M08; 2014M07; } \\
\text { 2014M12; 2015M09 }\end{array}$ & $\begin{array}{c}\text { 2011M05; 2012M03; } \\
\text { 2012M08; 2013M01; } \\
\text { 2014M06 }\end{array}$ & $\begin{array}{l}\text { 2012M01; 2012M06; } \\
\text { 2013М01; 2013М07 }\end{array}$ \\
\hline SWE & $2011 \mathrm{M} 12$ & 2010M10; 2012M05 & $2011 \mathrm{M} 12$ & 2011M08 \\
\hline TUR & $\begin{array}{c}\text { 2011M01; 2012M01; } \\
\text { 2014M06; 2015M02; } \\
\text { 2015M09 }\end{array}$ & 2011M04 & $\begin{array}{c}\text { 2011M03; 2012M01; } \\
\text { 2012M07; 2015M02; } \\
\text { 2015M09 }\end{array}$ & $\begin{array}{c}\text { 2010M05; 2011M04; } \\
\text { 2011M10; 2014M02; } \\
\text { 2015M03 }\end{array}$ \\
\hline
\end{tabular}

\section{Copyrights}

Copyright for this article is retained by the author(s), with first publication rights granted to the journal.

This is an open-access article distributed under the terms and conditions of the Creative Commons Attribution license (http://creativecommons.org/licenses/by/4.0/). 